\title{
Clientelism, Elections, and the Dialectic of Numerical People in Northeast Brazil
}

\author{
by Aaron Ansell
}

This paper explores rural Brazilians' interpretations of and ethical reflections on political clientelism. Brazilian elites often regard the people of the dry hinterland (sertanejos) as lazy, politically apathetic, and prone to corrupting democratic elections through the sale of their votes. Here I argue that the sertanejos living in the northeastern state of Piauí practice a form of clientelism that entails an ethical distinction between degraded vote buying and morally upright electoral transactions with politicians. For the sertanejos of Piauís interior, ethical electoral transactions do not corrupt democratic elections; they reverse the moral damage that elections themselves cause. Elections refigure socially embedded persons as numerical individuals destined to be added together as equal quanta of generic value. Ethical transactions reconstitute the voter's socially embedded personhood after the election has passed. However, rather than vindicating clientelism, this analysis draws attention to the social inequalities that prevent some people from practicing the ethical forms of political exchange. It therefore builds toward a standpoint for critiquing political clientelism that does not reproduce liberal idealizations of democratic citizenship.

In 2016, right-wing demonstrators throughout Brazil's metropolitan areas accused center-left President Dilma Rousseff of corruption, lending their support to her impeachment later that year. ${ }^{1}$ Far from the big cities, the subsistence cultivators and townspeople living in the dry backlands (sertão) of Piauí State anxiously attended to the media coverage of these impeachment proceedings. Few sertanejos doubted that "Dilma" had indeed engaged in illegal "accounting techniques involving loans from public banks to the treasury that artificially enhanced the budget surplus" (Gallas 2016). But perhaps even fewer cared. Dilma's Workers' Party (Partido dos Trabalhadores [PT]) administration and that of her predecessor (President Luiz Inácio "Lula" da Silva) had brought electricity and potable water to the villages where some $80 \%$ of the sertanejo population lived. They had facilitated poor people's access to small low-interest loans, expanded health services, and introduced a conditional cash transfer policy (Bolsa Família) that ameliorated both poverty and inequality.

Still, many people aligned with Brazil's increasingly powerful right-wing regard poor people's support for the PT as a sign of their tolerance of corruption, an attitude captured by the popular phrase rouba mas faz ("steals but gets things done"). ${ }^{2}$ For some critics, sertanejos' tolerance of Dilma's "corruption" confirms pejorative stereotypes of the region's population. The figure of the sertanejo is often cast as a backward hick who lacks political judgment, whose very language, the "mulatto,

Aaron Ansell is Associate Professor in the Department of Religion and Culture at Virginia Tech (242 Lane Hall [0227], Blacksburg, Virginia 24061, USA [aansell@vt.edu]). This paper was submitted 6 IV 17, accepted 1 XI 17, and electronically published 13 III 18. stony, near-unintelligible Portuguese of the scrublands," is inadequate to the communicative tasks of modernity, as discussed by Muniz de Albuquerque (2014 [1999]:130). Relatedly, the current Temer administration justifies its intended cuts to Bolsa Família by claiming that such policies amount to "institutionalized vote-buying" (Campos 2016). In short, conservatives characterize sertanejos as a party to corruption insofar as they sell their votes both to embezzling politicians who buy them off with food (or other material goods) and to "corrupt communist" presidents like Lula and Dilma who buy them off with redistributive cash stipends. ${ }^{3}$ Indeed, the caricature of the poor, lazy, dark-skinned, and overly fecund sertanejo combines the worst stereotypes of the US "welfare queen" with the added element of political soul selling.

Dilma's impeachment, pejorative stereotypes of the sertanejo, and the allegations of Bolsa Família's corruption frame

1. This paper emerged from the 2016 Wenner-Gren Symposium on "The Anthropology of Corruption." I am deeply grateful to Sarah Muir and Akhil Gupta for organizing and leading that symposium (along with Leslie Aiello, Laurie Obbink, and Soo-Young Kim) and for their invaluable feedback on earlier drafts of this essay. I am also indebted to all of my fellow symposium participants, who were likewise instrumental in shaping my interest and thinking about patron-client relations and the normative regimes condemning them.

2. For a discussion of the so-called rouba mas faz mentality in relation to the PT corruption scandals, see Balán 2014.

3. I know of no evidence supporting the accusation that Bolsa Família obliges the poorest to vote for PT candidates. Studies of Bolsa Família's beneficiary selection process have concluded the contrary, i.e., that it "did not include any partisan or territorial criteria” (Fenwick 2015:76). 
the forgoing analysis, but they are not its focus. Rather, what follows is an account of those electoral transactions that many statespersons (conservative and progressive alike) are prone to dismiss as vote buying. Scholars often label such transactions "political clientelism," the "exchange of political rights for social benefits" (Fox 1997:393). Here I explore the local political ethics governing such transactions in rural Piauí State, where I have conducted about 25 months of ethnographic research since 2003. While social scientists often distinguish clientelism from outright corruption (e.g., Hetherington 2018; Nugent 2018), which is commonly defined as "the appropriation of public resources for private gain" (Fukayama 2014:83), the distinction often collapses in practice. ${ }^{4}$ For instance, scholars and policymakers committed to normative (liberal) democracy readily describe clientelist exchanges as those in which the poor "are bribed into not pressing their material interests on their representatives who shape public policy" (Stokes et al. 2013:248). When considering why a voter would accept such a "bribe," such scholars point to "the greater marginal utility of income among poorer voters" (Stokes et al. 2013:89). This claim suggests that these voters know better but their desperation outweighs their political ethics. This approach risks projecting a liberal ethics onto these voters that obscures how they may well be acting within an alternative ethical framework, one that need not be predicated on the distinction between public and private resources.

The sertanejos living in southeast Piauí certainly understand the modern distinction between public and private spheres of activity, but that distinction does not necessarily organize their voting ethics. The sertanejos I have come to know have long exchanged their votes for many kinds of material goods, and they regard only a subset of such exchanges to be ethically reprehensible - that is, "corrupt" (although they only occasionally use the term corrupto in reference to the degraded exchanges). They have traditionally considered other political transactions (equally as "clientelistic" by liberal standards) to be morally upright. ${ }^{5}$ Here I argue that this local distinction is shaped by the institutional mechanics of modern elections (mainly municipal elections), which deform the voter's self in a way that requires redressive action. Moral political transactions serve that purpose. ${ }^{6}$

4. Several studies do posit mutual causation between clientelism and corruption in a way that affirms their conceptual distinction (e.g., Kawata 2006; Singer 2009).

5. During my visits to Piauís sertão in the decade following the establishment of Bolsa Família and other PT policies, I have increasingly heard my sertanejo associates use the phrase "we are no longer stupid" to critique the very ethical distinction that I have discussed throughout this essay (see Sharma 2018 and Tidey 2018). Such claims suggest that an incipient liberal electoral ethics may be replacing that which I have described here, although it is also possible that transformations in political ethics are occurring that are not reducible to "liberalization."

6. There is nothing novel about the claim that clientelist relations include an internal ethical component, but because those relations are often
Modern elections with universal suffrage and one vote allocated per person rest on the principle of methodological individualism. This principle derives the social whole from its individual parts. The election encourages voters to see themselves as individual parts, each voter formally equal to the other and able to steer himself or herself within a social space in which none is anchored within any hierarchy or network of obligation. Here I draw on Roberto DaMatta's (Dumontian) distinction between the "person," as a relational being "complementary to all others" and "submerged within a totality to which it is necessarily bound," and the "individual," who is "equal and parallel to all others" with "private' (or inner) emotions" and a "right to its own space" (DaMatta 1991:170-177). The dominant construction of the self in Piauís sertão combines elements of both ideal types. Certainly, people talk about individual character and attribute a (Christian) spiritual equality to all people. At the same time, they reckon their relations to others in terms of their relations to those people's family groups, attributing other's character traits, privilege, and culpability to families (and villages), and they proudly express their own dependence on prestigious persons, as if to partake of the latter's honorable identities. Despite this complexity, I submit that the dominant idiom of the sertanejo self is that of the person.

In this context, an election reduces sertanejo persons to numerical individuals, each endowed with, and in fact equated with, a single quantum of generic value. This value makes the voter's self into something "destined to be counted," like notches on a politician's bedpost (Châtelet 2013:36). To identify one's self with this quantum of value is to experience the social field as a staged "Galilean thought experiment," as epistemologist Gilles Châtalet calls it, one that works by first "stripping bodies of their qualities" and then by deriving truth from the movement of these human particles within "an infinite space purified of all forces, of all friction" (Châtalet 2013:36). The deper-

positioned outside modernity, the nature of clientelist ethics is easily misconstrued. Michael Herzfeld (1987), Ana Claudia Marques (1999), and others have argued that the term "patron-client relations" has been historically applied to Mediterranean societies in ways that exaggerate certain facets of these societies, such as honor and shame, while backgrounding others. Clientelism's stereotypical opposition to modernity leads some scholars to frame its ethical aspects as precultural human features, "rooted in . . basic biological principles [by which a person] instinctively tends to favor relatives" (Fukayama 2014:88). Alternatively, scholars who discuss clientelist ethics in cultural (rather than biological) terms often focus on features familiar to the Weberian ideal type of a patrimonial society, such as loyalty (Boissevain 1977:81; Gellner 1977:2), obedience (Gellner 1977:2), friendship (Pitt-Rivers 1954; Wolf 1966), reciprocity (Silverman 1977:10), security (Scott 1977:27), valor (Gellner 1977:2), protection (Scott 1977:23), interpersonal trust (Roniger 1991), family (Banfield 1958), honor (Gellner 1977:2), and pious intercession (Boissevain 1977; Rassam 1977:159). Modern clientelist morality, however, is less a patrimonial holdover and more "an addendum" to other "official modes of organization" (Gellner 1977:3; Landé 1977). Scholars of clientelist ethics should therefore view clientelist practices as corrective supplements to the dislocations of such official modes of organization, here explored in terms of elections. 
sonalizing dynamics of elections dissolve hierarchical groups (e.g., extended families) into monadic particles that can then be reassembled as aggregates of individuals who are added together to produce "our side" and "their side" (i.e., the official multiparty coalitions that arise during the campaign season). Because they experience this dissolution as a deformation of their personhood (albeit one with which they are complicit), sertanejos hold their politicians accountable for reaffirming their socially embedded identities in the aftermath of an election.

What makes this dissolution of the voting person reversible is something akin to what Brazilian literary critic Roberto Schwarz calls "favour," the gift that a "man of wealth and power" gives to a "free man" who, prototypically, is his "aggregado," that is, one who is annexed to his family (Schwarz 1992:22). Here I use "favour" (preserving the British spelling of Schwarz's English translation) to refer to those sertanejo political gifts that entail a similar act of encompassment, one that affirms the recipient's personal prestige and the prestige of his or her particular family through the idioms of long-term care and friendship. Understanding the internal ethics of "political clientelism" in these terms militates against any dismissal of clientelist subjects as morally disassociated as well as any tendency to plot this subject's teleological transformation into a liberal citizen.

Here I do not seek to venerate "political clientelism" as a political form; rather, I illuminate clientelism's "quasi-universal social mediation" (Schwarz 1992:22). Such quasi universality can be seen in the local aspiration for unalienated exchange, for a part of the voter's selfhood to remain attached to his or her vote, so as to ensure that the voter is not permanently transformed into an instrument of another's advancement. This impulse is formally (although not substantively) similar to the liberal ethic that condemns the clientelist alienation of those "(v)otes that are purchased [and that therefore] carry little information about the preferences of the person who sold them" (Stokes et al. 2013:253). Moreover, sertanejo political ethics militates against the permanent reduction of persons to numerically instrumentalized selves and thereby manifests a version of Kant's categorical imperative, that people not treat one another as means to ends. Yet for all this, the local distinction between moral and degraded electoral transactions mystifies the fact that not all sertanejos enjoy equal access to the morally upright transactional forms. Social marginality based on wealth, gender, race, and kinship inhibits such access. Here I turn a critical eye toward these inequalities and explain their relevance for current debates about antipoverty policy.

First, I sketch a history of Brazilian elections in terms of the conceptual issues introduced here. Then, I turn to southeast Piauí to focus on local distinctions between two types of electoral transaction. I analyze these two transaction types in terms of their ability (or failure) to restore numerical individuals to their preelection condition of prestigious personhood. I work through a case study that shows how social inequality produces differential access to these transactional options as well as how inability to access moral, long-term transactions can exacer- bate a person's social marginality in the long term. In my concluding remarks, I reflect on the implications of this analysis for current debates about Brazilian antipoverty policy.

\section{Elections, People, and Individuals}

After Brazil's independence from Portugal in 1822, the parliamentary elite who ruled the Brazilian Empire (1822-1889) from Rio de Janeiro established a new system of indirect elections (for parliament as well as local positions) that reflected their ambivalent adoption of European liberal ideals. Formal political equality, even limited to free and propertied men, conflicted not with the hidden reality of social hierarchy (as it did in Western Europe) but with the blatant appearance of hierarchy in everyday life (Schwarz 1992:23). ${ }^{7}$ Twentieth-century thinkers argued that the hierarchical sociability of Brazilian life derived from the colonial plantation, where the seigniorial patriarchs of large rural estates ruled over an attaché of dependent children, slaves, and free dependents (aggregados). Sérgio Buarque de Hollanda, in his seminal work The Roots of Brazil, summarizes: "The private sphere invaded the public, the family invaded the state" (2012 [1936]:53). The seigniorial patriarch functioned as the stand-in for the colonial (and later imperial) state, dispensing justice and government resources to his dependents with full discretion. The patriarch's dependents (even free persons) were not treated as discrete individuals but rather as extensions of the patriarch who "bore responsibility for the actions of those whom he led" (Graham 1990:22; and see Holston 2008).

This deeply hierarchical form of sociability was hard to reconcile with basic electoral procedures, even though the latter had been quite limited. During the "Second Empire" (18401888 ), liberal elites in the capital generally promoted the cancelation of literacy requirements for voters and the consequent expansion of suffrage to all men (which occurred in 1881; Porto 2002:100-107). Yet they, like their conservative counterparts, feared this measure would turn the "unknown multitudes" into "blind instruments - either of individual passions or of the authorities," a worry exacerbated by the perceived inevitability of abolition (which occurred in 1889; Graham 1990:190). Liberals and conservatives in the capital shared the concern that enfranchising "the rabble" would deliver them into the hands of the wealthy rural aristocrats to whom they were beholden in daily life. The agrarian elite would "bridle" these dependents and "corral" them into voting blocs that they would use to secure regional autonomy from the central government (Nunes Leal 1977 [1949]:21). The central government therefore took various steps to minimize this "bridled vote," such as limiting suffrage to men who lived outside their fathers' houses and whose occupations made them independent of paternal control (Graham 1990:103, 105).

7. See Graham 1990:103. 
Underlying elite concerns about the centrifugal pull of regional land bosses was the more general impulse to protect the social fabric itself from the destabilizing potential of the vote. The perceived threat of the vote was not so much that the popular classes would affect revolution through the ballot. (The candidates were often ideologically indistinguishable, and anyway, the elections' outcomes were often rigged.) Rather, their very possession of the right to vote jeopardized a social order predicated on hierarchy. Thus, elites at local levels enacted a host of supplemental electoral rituals that dramatized each voter's position with respect to local elites, such as the requirement of elite witnesses to testify to the trustworthiness of poor voters (Graham 1990:112). Framed by such practices, electoral "participation served not to manifest an egalitarian ideology, but to ensure that some would be called upon to play bit parts while others of higher standing stood in the spotlight" (Graham 1990: 120-121; and see Holston 2008 on other legalized inequalities). These rituals militated against the election's potential to decompose hierarchical groups into aggregates of relationally unfixed individuals corralled by "local bosses . . . leading swarms of electors as one drives a herd of donkeys" (Nunes Leal 1977 [1949]:16).

During the twentieth century, changes to the law brought electoral institutions more in line with liberal thought. Ironically, Brazil's authoritarian regimes affected some of these changes. Under Getúlio Vargas (who would later assume dictatorial powers), suffrage was extended to women and the vote of all enfranchised persons was made compulsory and secret (Holston 2008:105; Silva and Silva 2015). Later, during the military dictatorship (1964-1985), the Electoral Code made it "unacceptable . . . to give, offer, promote, solicit or receive for oneself, or another, money, gifts or other advantage to obtain a vote" (Tribunal Superior Eleitoral Brasileiro 2016, Art. 299). During redemocratization, the literacy requirement was removed (1985) and multiparty competition allowed (1979). In Piauí, this coincided with increased competition among politicians and an increased choice of alliances for the rural poor.

Today, in Brazil's small rural municipalities, ordinary people lament the factional rancor that penetrates everyday life every 2 years during the "political season" (época da política), the phase of intensified coalition building that begins a few months before the onset of the official campaign season (July) and continues through the October election day. ${ }^{8}$ Municipalities bifurcate into two warring factions, each of them aligned with a candidate for mayor and his or her associated legislative candidates (vereadores). During this phase, "politics" is "above all conceived as an activity, which ... has an invasive character ... and penetrates relations and domains from which it should be excluded (kinship, art, religion)" (Goldman 2013:9091, emphasis in original). I understand this "invasive character," as anthropologist Marcio Goldman calls it, to derive not only

8. Elections, and thus "political periods," occur every 2 years due to staggered, 4-year municipal and state/federal cycles, although the local processes in question here are more acute during the municipal elections. from the penetration of one's intimate group by factional concerns but also from the refiguration of one's group as an aggregate of individuals, each of whom can "go where I please" (as Piauienses say) - that is, choose whom to vote for and, crucially, whether to "follow" another (e.g., a parent, a spouse, or a local community organizer) in one's vote. This is perhaps why anthropologist Moacir Palmeira insists that "for the [rural Brazilian] elector, what's in play in an election isn't the choosing of one's representatives, but the situating of one's self within society" (1992:27). What Palmeira calls the "adherence vote" (voto de adesão) rightly presupposes a subject who has already been desituated from society, who moves around like a free particle. I suggest that we can discern two modes of self-situating that both operate during the election cycle: one is the aggregation of (particalized) individuals under the banner of a candidate, and the other is the postelection resituating of one's self as a person within family-based hierarchies.

In the next section, I try to illustrate the way elections promote an experience of the self as a countable individual and how they later help certain people reestablish prestigious forms of socially embedded personhood. I discuss two modes of (clientelist) electoral transaction that strike Piauienses as morally distinct because they affirm voters' postelectoral personhood to different degrees.

\section{Moral Reasoning and Modalities of Electoral Transaction}

During the political season, sertanejos often lament to one another the "tearing apart" of friendships and neighborly relations due to factional adversity. They blame the "fanatics" among them, those who are "sick" (doente) for their chosen politician, who scream and pick fights with adversaries. Many claim to keep away from the loud noises of the campaign and from self-seeking politicians who reduce their value to their vote. "You think they're smiling at you, but they're smiling at your vote," as one woman said. Yet this experience of objectification also has its allure.

A telling incident occurred in May of 2004, during "the politics." It involved a gay man who was the municipal nurse and the only person I knew who was "out" in this generally antigay setting. The nurse, who was accustomed to daily jokes and low-grade sexual assaults, became the victim of some nasty political bullying when he told the mayor that he was uncertain "who will have my vote this year." The mayor's son-in-law, upon hearing the remark, slapped him across the face, saying, "You'll vote for your mayor, faggot (viado)!" Such acts of physical aggression are rare but not unheard of during the political period, when "things get hot." Still shaken, the nurse later vented to me, "I have my defect, but I'm a citizen. I have a right to my own vote. I go where I please!" Sometime later, I saw him carousing with other men in a bar owned by the son of the opposition candidate, "Henrique." It seemed to me that the men in the bar (mostly Henrique's followers) were treating the nurse rather well: one clapped him on the back, and 
another filled his glass with beer. The town prostitute (the nurse's friend) was also there, sitting on one man's lap, then another's . . . then the nurse's. One man approached the chair from behind, grabbed the nurse's hands, and squeezed the woman's breasts with them while laughing, an act that I construed as a playful (if assaultive) form of "straightening" the nurse. When Henrique won the election for mayor that year, the nurse went on to act as an important player in his extralegal health care network. One of Henrique's allies later said of him, "He has his defect, but he knows how to care for others."

I do not know what, if any, material good Henrique gave the nurse in exchange for his vote that year. Regardless, once the nurse promised his vote to Henrique (or made overtures to that effect), he was swept up into egalitarian and quasianonymous Rabelaisian festivities. By "quasi-anonymous," I just mean that, while everybody knew him (and his stigmatized sexuality), they playfully erased his particular identity so that the nurse could become just one of the guys, one of Henrique's voters. The nurse's "conversion" into a vote-possessing individual suspended his subaltern personhood and issued him an anonymous freedom to "go where I please." It was the nurse's freedom of movement that made him available to affiliate with Henrique's faction, to allow Henrique to enclose him in his "corral" (curral). Moreover, afterward, Henrique's "favour" helped to redeem his social specificity by placing his professional identity under the aegis of Henrique's postelectoral hierarchy.

The festive events that candidates sponsor during the political period are occasions when people like the nurse can partake in such playful suspensions of identity. Both within and outside of these festive occasions, the head candidate's supporters make use of an absolutist moral discourse that equates all those on "our side" with "the people" (o povo) and depicts those on "their side" as the perfidious few (a boca preta, literally "the black mouths") who profit at the people's expense. One unofficial slogan that circulated in 2004 went, "If God is for us, who would be against us?" The slogan is, among other things, depersonalizing; it links the voter's virtue as a generic Christian (Catholic or Evangelical Protestant) to her generic membership within a politician's faction, as is common throughout Northeast Brazil (Maya Mayblin, personal communication, July 2017).

Not all talk during "the politics" erases people's social specificity. In everyday talk during the campaign (often occurring in small bars or on the front porches of private homes), people recount personal misfortunes that they attribute to the wrongdoing of rival candidates. Members of the same faction elicit and circulate one another's accusatory narratives so as to specify the stakes of the election to particular persons and families. At the same time, however, when various person's stories are relayed in the same conversation, speakers calibrate their plots, making their protagonists analogues for one another. The circulation of personal stories becomes another means to fold particular people into aggregates of individuals associated through political allegiance.
This shift from the particular to the generic expression of the voter's selfhood also plays out within a genre of private negotiations between candidates and families. During the early months of "the politics," politicians visit the homes of prospective electors to present them with "proposals." Typically, the candidate knocks on the door, is invited in to enjoy the family's hospitality, and then asks, "What do you need here?" What follows is a sequential revelation of reciprocal need, the politician's need for votes and other campaigning support and the voter's need for farm inputs and household repairs. What follows is a sequence of patron-client bargaining (Ansell 2014; Marques and Villela 2016). This genre of bargaining, which dates back to at least the mid-twentieth century, has traditionally culminated in the posting of a generic sign on the door or outer walls of the home, the candidate's propaganda sticker. ${ }^{9}$ The household head may post multiple copies of this sticker to the exterior of their home, a quantity correspondent to the number of household votes promised to the candidate.

Male household heads have traditionally expected wives, children, and other coresident dependents (e.g., junior siblings) to "follow father in the vote out of respect." time my fieldwork began, this expectation was fading. Yet, many families still vote in unison for strategic reasons. The sum of the votes that a family head (man or woman) can dedicate to a politician determines their leverage in negotiating politicians' favours, both those that the politician promises before the election (e.g., a sack of cement or a municipal job to a family member) and those favours that a voter might solicit during an unforeseen emergency after the election (see below).

The fact that some dependent junior kin cannot easily "go where I please" does not inherently trouble the claim that social relations during the political period approximate Châtelet's "Galilean thought experiment." Instead, it reveals the logic of a numerical game based on "capturing" (captar) or "conquering" (conquistar) votes. Politics, for candidates and family heads, entails the immobilization of individuals, the art of locking others into commitments and then making those commitments publicly visible and countable. Posted on a household's outer wall, a candidate's propaganda stickers indicate that the household is "fechado" (locked in, literally "closed") for such-and-such a politician. The same can be done at a higher level of aggregation. Often, contiguous groups of five or 10 households within a village will bear identical adhesive propaganda. These are often the multifamily aggregates that a village leader (a church deacon, community association president, or wealthy neighbor) has "locked in" on a candidate's behalf (see Palmeira

9. My field consultants have noted a decline in this practice since the early 2000s. Elsewhere (Ansell 2015), I have tried to explain its decline in terms of the public's increasing internalization of liberal critiques of patron bullying as well as a more endogenous grievance that blames this propaganda for limiting local modes of agency.

10. Minors at least 16 years old can vote in Brazil, although their vote is not mandatory, as it is with other adults. See Heredia 1996 for a discussion of voting and family gender dynamics in the rural northeast. 
1992 on "electors with multiple votes"). When these prestigious villagers attend festive events during "the politics," they make a show of how many electors they have "captured" by ushering them into open-air passenger trucks and transporting them to the events. As these trucks arrive, politicians count their occupants before they disembark. The sum serves as a numerical gauge of the local leader's prestige and determines the amount of resources the politician will invest in these informal leaders (see Szwarcberg 2015:76 on "brokers").

Candidates may or may not negotiate specific exchanges in the homes of those individuals already "captured" by local leaders. Even if they do not, these electors trust that their candidates will be reliable sources of support during times of need (see Roniger 1991 on "trust" in Northeast Brazil). The idiom of "friendship" (amizade) establishes this norm (Alencar Chaves 2003:43-53). When I asked Henrique why, after the election was over, he provided emergency bus fare to transport a sick person to an urban hospital, he said, "I'm always a friend to my friend." His "always" resonates with other temporally sensitive expressions of friendship. A good politician is one "for all seasons" (de todos os tempos) and one who "always walks around here" (sempre anda por aqui). A bad politician is one who "only wants your vote" and "only gives you value (valor) during the political period." While politicians may boast of the enduring loyalties they have earned from village families who vote for them in sequential elections, they know that they need to do their part to secure these loyalties against the shifting sands of familial and neighborhood obligations (e.g., work partnerships, love affairs, and land disputes) that alter people's thinking about whom to vote for during the next election. Each subsequent "proposal" visit implicitly affirms that a voter who was once captured in their numerical individuality has returned to live as a socially embedded person whose particularity awaits rediscovery.

But politicians do not always do that. They view some voters as unworthy of such affirmation because they are embedded as marginals vis-à-vis their local community. Such people's votes are simply "bought."

In contrast to the morally upright variety of electoral transaction described above, Piauineses regard as "corrupt" (corrupto) or "shameless" (sem vergonha) the purchase of individual votes with cash, what they call "vote buying" (compra de voto).${ }^{11}$ Individuals who "sell" their votes are reputed to attend any and all campaign festivities, feigning commitment to whichever candidate sponsors these events. Some of my neighbors in Piauís villages admitted to doing as much, but they insisted that they simply had yet to make up their minds about their voting intentions. Politicians try to court the votes of such persons, but they complain that many are untrustworthy. They call them "tricksters" (enrolões) or "broken-down people" (desman-

11. Turid Hagene (2014) has also observed elsewhere in Latin America (Mexico) that "political clientelism and vote-buying are two different practices" when "seen from the clients' and the brokers' point of view" (Hagene 2014:1). telados), although it seemed to me that many self-respecting persons did not receive candidate visits in their homes. To me it seemed less a matter of personal character and more a function of less prestigious people's inability "to furnish votes for the politicians, either because they do not maintain control over their own resource-as-votes . . . or because, for whatever reason, they fail to convince candidates of this control, or of their exclusive loyalty" (Villela and Marques 2006:36).

Instead of visiting such people in their homes with a "proposal" during the campaign, candidates (or their associates) try to capture their votes the night before the elections. They stuff themselves with bills and ride their motorcycles into poor communities, arriving discretely by the back roads. They offer these "broken down people" the going rate for a vote in the upcoming election (US\$20 in 2004, increasing to US\$100 in 2012). By making this deal, the voter gives no further commitment, promising neither to display the candidate's propaganda nor to vote for him or her in subsequent elections. And the politician makes no commitment to serve as an available font of the sort of postelectoral gifts that affirm the voter's prestigious positioning within village-level hierarchies - indeed, they often "don't even say hello" to such voters following the election.

Piauienses typically associate gifts of cash and booze, as opposed to jobs and farm inputs, with degraded political exchange. As one villager commented, "It looks ugly, a man taking cash. I've taken cash, but it's not right. Henrique should know we value his heart, not just his wallet." Yet it is not the use of cash per se that sullies these transactions; giving a voter cash earmarked for a medical procedure carries no stigma. However, when cash "is presented in its purely monetary form, it turns instantaneous and finite a relation (elector/candidate) whose elongated duration . . . is many times more valuable" (Villela 2005:269, my translation). Here anthropologist Jorge Villela frames vote buying (in the neighboring state of Pernambuco) as a truncation of social relations otherwise expected to last for an "elongated duration." His insight extends to Piauienses, for whom a moral vote is one that retains some part of the voter's self - a vote that serves for the politician as a durable index to the voter's personhood and motivates postelectoral favours. By contrast, in what Piauienses call "vote buying," the politician carries away a vote that exerts no force pulling him back toward an ongoing reciprocity with the voter as a socially embedded person.

In this section, I have tried to answer a question posed by political scientists: "Within the broad category of clientelist exchanges ... [w] hat affects the types of benefits that voters demand, or that politicians choose to supply?" (Hicken 2011: 305). The salient distinction I have presented does not revolve around the familiar liberal binary: private bribes versus "programmatic club goods . . . distributed according to well-defined rules and without regard to partisan characteristics or voting history" (Hicken 2011:294). Rather, this local moral distinction opposes short- and long-term exchanges involving private (and sometimes public) goods. This distinction is familiar to anthropologists who have found that people in various cultural 
settings ascribe legitimacy to long-term "transaction orders" associated with the maintenance of the cosmos and deny legitimacy to short-term transactions associated with individual self interest (Bloch and Perry 1989; see also Elyachar 2005; Ferguson 1994; Munn 1992). Here it is enough to note that honorable completion of these long-term transactions affirms the voter's value as a socially embedded person whose prestige motivates ongoing friendship and favour with a politician. The axiom that would seem to gird moral electoral conduct in this clientelist system might be expressed as "People who become numbers for one another should turn back into people for one another" (cf. Kant's second formulation of the categorical imperative as the need to treat people as ends in themselves; Kant 2002 [1785]). Yet this ethic is not fully universal; it extends only to a politician's own voters. Indeed, these are the people she or he "uses" as numbers in the first place.

This account of clientelist ethics in Piauí's sertão highlights ordinary people's preoccupation with the preservation of their prestigious embeddedness within everyday hierarchies in the aftermath of elections. But it also suggests a certain mystification of electoral transactions insofar as people blame voters' bad character ("tricksters" and "broken-down people") for their "choice" to engage in degraded transactions. In the next section, I explore how social inequalities at the village level impede access to honorable political transactions.

\section{Unequal Access to Moral Transactions}

When I first went to live in the remote Afro-Brazilian village of Caixa de Água in early 2004, the "white" people from the municipal hub teased me that I would come running back once that "bunch of blacks" (a negrada) and "drunkards" (cachaceiros) scared me off. Very few of this village's residents reported having long-term alliances with the erstwhile mayor (Henrique's rival) nor with any of the mayors who preceded him. He "has not stepped in our village in years," several told me. "He just sends his ass-kissers (puxa-sacos) to buy our votes." Others lamented their abandonment: "We only have value (tem valor) during the political season." Several reported the mayor to have said of the village residents, "If you set fire to them all, the only thing [worthwhile] you would lose would be the match."

In this section, I take another pass at Allen Hicken's question, "What affects the types of benefits that voters demand, or that politicians choose to supply?" (Hicken 2011:305). While Piauienses often attribute the "types of benefits voters demand" to personal character, village-level inequalities clearly limit access to moral, long-term political transactions to those people who already enjoy some local prestige. The very concept of "prestige" ( prestígio), a term used even outside the political period, imposes a unity and "grade-ability" on multiple worth-creating factors within a person's life. Some such factors are already objectified in quantifiable form, such as salary, number of hectares owned, heads of livestock, number of children, and so on. But prestige also derives from more labile relational factors, such as reliability for day-trading labor exchanges, propensity to grow violent when drunk, discreteness in sexual liaisons, and so on. If one's intravillage prestige remains vague, situational, and mutable during everyday life, during the political period, electoral transactions reify and quantify local prestige by translating it into a sum of votes and then exchanging that sum for valued goods (visible to one's neighbors).

Many of Caixa de Água's residents “opened our doors” to a politician and "put his face [propaganda sticker] on our house," because they wanted not only specific resources but also an ally "for all seasons." Yet many found their postcampaign requests for building materials or medical procedures unanswered. They were given no favours that affirmed and assisted their conversion back from captured vote-bearing individuals to socially embedded persons. The politicians' resource-maximizing strategy (i.e., their prioritization of "electors with multiple votes") motivates them to predict which local electors are likely to "lock in" others' votes, and they show remarkable attunement to variations and fluctuations of villagers' local prestige. In making such rational decisions about resource allocations, politicians reflect back to the community a numerically expressed assessment of its members' relative prestige, and these assessments then affect village-level inequalities.

The unfortunate case of Dona Rosalda reveals the mutual influence linking political transactions to intravillage status. When I met her in 2004, Rosalda (who was approximately 50 years old) was already widowed and living in a decent house within a cluster of homes occupied by several of her sons, who visited her regularly. I found her warm and clever, and I became especially close with one of her sons, Pedro, an Evangelical Christian and shop owner. Pedro kept his brothers on the straight and narrow, and his church attendance kept him and his mother connected to the village's powerful "Silva" family. The Silvas held a usufruct title to the lands on which many people, Rosalda included, built their homes. The Silvas had, in one member's words, "allowed Rosalda to stay" because her late husband belonged to a "distant branch" of the Silva family.

During the 2004 political season, Henrique courted Rosalda's vote and, through her, those of her children, all of whom the erstwhile mayor had "left dissatisfied." Rosalda helped Henrique gain his foothold in the village by letting him use her home to throw a political festa. She spoke highly of him, posted his propaganda stickers on her door, called him by his endearing nickname, and counted herself as gente de Henrique (one of Henrique's people).

Rosalda's life went downhill during Henrique's time as mayor (2004-2012). Pedro and his family moved away, and another son joined with an estranged Silva nephew in committing small acts of theft in the village. Henrique probably learned of Rosalda's misfortunes from a man named Valdo, a Silva who served as the deacon of the village church. Valdo had shown considerable charisma and intelligence by organizing the church's refurbishment, and when Henrique heard of his success, he gave Valdo his cell phone number and told him to 
"call me whenever someone is in [health] trouble, and I'll send a car." He even bankrolled Valdo's (unsuccessful) campaign for town alderman in 2008. That same year, Rosalda's wayward son and his accomplice targeted Valdo's uncle in a robbery. Valdo was enraged, and without Pedro's church presence to temper his condemnation of Rosalda's family, Valdo probably spared little charity for Rosalda herself when relating the story to Henrique.

Henrique disappointed Rosalda sometime during his second mandate (2009-2012) when another of her sons suffered a broken leg and needed surgery to reset the bone. The injured man had asked Henrique to pay for the surgery (outside of the political season), but Henrique told the man to "have patience." Recounting this to me in 2014, Rosalda yelled in frustration, "How can a person have patience with a broken leg?" and swore she would never vote for Henrique again. Speaking of the Silvas who remained loyal to Henrique, Rosalda quipped that "they wait for him with their little mouths open" (perhaps like baby birds in the nest).

Still in 2014, Rosalda found herself in a kind of last-ditch bid to regain standing in her village. Her wayward son had come up with a plan to divest the Silvas of their lands. He enlisted the aid of a white man, Clebson, who lived in a neighboring village and who was on the payroll of the new mayor, Henrique's successor and rival. Both that mayor and Clebson signed a document implying that some of the Silva lands belonged to Clebson, who Rosalda said was "the real representative of our community." Rosalda began posting the new mayor's propaganda materials on her door, and for a while her home became the hub of Clebson's village supporters, many of whom were among Caixa de Água's poorest residents, people who she said were "fed up with Henrique and all of his nauseating people (the Silvas)." But their faction lost the matter in court. The Silvas succeeded in debunking Clebson's document, thanks in part to the lawyer that Henrique had hired for them. Rosalda took to drinking and became the butt of jokes. The police beat up her wayward son, and she had no recourse to justice, even though the mayor (Henrique's rival) had ostensibly been her ally.

In 2015, she complained to me that she could not even get the mayor to pay her daughter's bus fare to the capital city: "He was not there for me during the time of need (a hora de precisão)! I gave my vote to him. I didn't have to do this. I could have given my vote to another! . . We here only have value during the political season." What struck me as particularly poignant was Rosalda's reliance on the vote as a register of personal worth at a point in her life when her other fonts of extra-electoral prestige had collapsed. I note that she first insists that her mere possession of a vote should be enough to secure a politician's friendship during her "time of need," but she then acknowledges that a vote, by itself, does not do this. She depersonalizes this failure by framing it as a shared experience among her fellow villagers ("We here").

But not all her fellow villagers did share that experience; the Silva's votes did secure politicians' friendship. It was Rosalda's low prestige (and that of some others in her village) that allowed Henrique, and later the other mayor, to forget his responsibility to her. Focusing on Henrique, he likely made the choice not to help her son, because he knew that Rosalda had lost influence over her son's (and daughter-in-law's) votes due to changes in kin residence, kin behavior, and interhousehold conflict.

It seems, then, that politicians tend to withhold from people like Rosalda the kinds of honorable exchanges outlined in the previous section, treating them like people "who only have value during the political season." And conversely, the diminution of someone's numerical value as an elector (from several votes to only one's own) becomes a register for her general worthlessness to her neighbors after the electoral period passes and so creates a vicious cycle. I see this vicious cycle as the basis for a critique of sertanejo clientelism that hews more closely to sertanejos' experiences than do liberal critiques of clientelism's alienation of the vote from the citizen's political will.

\section{Conclusion}

I have tried to illuminate the ethical and practical distinctions that animate sertanejos' engagements in political clientelism in rural Piauí State. From within a liberal perspective, all such practices are tantamount to vote buying (hence bribery), and they corrupt elections because "(v)otes that are purchased carry little information about the preferences of the person who sold them" (Stokes et al. 2013:253). For sertanejos in Piauí State, however, a corrupt vote is not one that lacks information about voter (policy) preferences but rather one that carries little obligation to affirm the voter's personhood (as in Mauss 1950 [1925]). The immoral vote is one that encourages a politician to leave the voter in a state of liminal individuality, rather than assisting the voter's return from that state to one of socially integrated personhood. At the heart of this analysis is the claim that modern elections, organized by the principle of methodological individualism, presuppose a society comprised of freemoving particles, and this does not fit with the default understanding of the self-as-person (à la DaMatta [1991]) in this context. Nonetheless, sertanejos play brilliantly the local power game that has developed in relation to electoral rules, avidly transfiguring themselves into countable subjects and even facilitating their counting through the decoration of the homes. They have much to gain from doing so: not only a negotiated resource received in direct exchange for their vote(s), but also an ongoing gift-bearing friendship that boosts their local prestige. A politician's friendship signals that the voter is worth more than his or her vote, that his or her personhood overflows their status as voter. As such, the moral vote reverses the voter's liminal transformation into a quantum of value and restores his or her default personhood.

I have described this transformative process with attention to sertanejos' performances of, and reflections on, self and groupness manifested during the "political period." Sertanejos lament some aspects of their transformation into numerical individuals, such as the aggressive fanaticism, the breakdown 
of neighborly relations, and the objectification of one's worth in the eyes of politicians who "smile at your vote." And they enjoy others, such as the dissolution of their particularity into celebratory crowds, the effervescence of gifting and rumor, and the vitality of controlled conflict. Becoming a countable unit of value also affords one a distinct form of agency during the political period; this consists in the steering of one's vote until one must eventually allow it to be "locked in" by another person, a politician or a more prestigious neighbor. The end of the election signals the release of this lock and the freedom to once again navigate one's friendships and labor relations and to rediscover one's personhood in relation to imagined groupings. This is inevitable in all cases - nobody remains a free-moving particle-but only in some cases do politicians contribute to the affirmation of the voter's postelectoral personhood: only in cases where it is "worth it" to them. And such judgments can have unjust causes and cruel effects.

Therefore, while this analysis asserts distance from liberal critiques of clientelism, it does not forgo critique altogether. Rather, it points to the failures of this particular form of clientelism to affirm and aid people, like Rosalda, who long for the consummation of electoral transactions only to be disappointed. In explaining such disappointments, rural Piauienses often point to the character defects and misdeeds of voters and politicians alike. But equally relevant are the intersecting dimensions of subalterity (e.g., Rosalda's poverty, race, widowhood, and familial abandonment) that reduce people's interhousehold prestige and make them less "worthy" of politicians' investments.

By way of postscript, it bears noting that former President Dilma Rousseff once boasted that her party's Bolsa Família Program "swept away hundreds of years of clientelistic politics" through the transfer of funds from the state to the poor (Braga 2013). This same program now stands in jeopardy, as the conservative interim government of Michel Temer "promotes the biggest cuts [to Bolsa Família] in history" (Brasil de Fato 2017). Debates over the fate of this policy raise the question of how such redistributive policies interact with sertanejo political ethics and categories of electoral transaction.

Given that poverty can diminish prestige and thus impede access to virtuous transactions, Bolsa Família's monthly cash stipend may broaden access to the sorts of long-term patronage "friendships" described here. Moreover, because the cash grant offsets the need for unmarried youth to leave their parents' household in search of migrant labor, it can improve the household's prestige by increasing the number of votes its senior heads can commit to a politician (Barbosa 2006). Bolsa Família may also improve household prestige by affording grant-holding parents (especially mothers) added leverage over their children's voting behavior. ${ }^{12}$ Increasing household eco-

12. The Bolsa Familia cash grant is preferentially given to female beneficiaries. There is some research suggesting that this has increased women's economic power, leading to "a strengthening of women's autonomy in the household” (Peixoto 2010:169). nomic wellbeing may therefore push sertanejos away from "vote buying" and toward electoral transactions that pressure politicians to support them during "all seasons." At the same time, Bolsa Família and other related programs may also cause a shift in local political ethics toward liberal sensibilities. Not only do the program's federal and state representatives explicitly decry clientelism (Ansell 2014), the relative stability of Bolsa Família's stipend (and supportive services) throws into relief the periodic failures of local politicians to sustain moral friendships even with prestigious households. As a result, people may no longer wish to render themselves countable during election time.

\section{References Cited}

Alencar Chaves, Christine de. 2003. Festas da política: uma etnografia da modernidade no sertão (Burutis/MG). Rio de Janeiro, Brazil: Relume Dumará.

Ansell, Aaron. 2014. Zero hunger: political culture and antipoverty policy in Northeast Brazil. Chapel Hill, NC: University of North Carolina Press.

-2015. Democracy as the negation of discourse: liberalism, clientelism, and agency in Brazil. American Ethnologist 42(4):688-702.

Balán, Manuel. 2014. Surviving corruption in Brazil: Lula's and Dilma's success despite corruption allegations, and its consequences. Journal of Politics in Latin America 3:67-93.

Banfield, Edward C. 1958. The moral basis of a backward society. New York: Free.

Barbosa, Adauri Antunes. 2006. Bolsa Família causa migração de retorno. $O$ Globo, November 12. http://desenvolvimentosocial.sp.gov.br/lenoticia.php ?id = 683 (accessed June 20, 2016)

Bloch, Maurice, and Jonathan Parry. 1989. Introduction: money and the morality of exchange. In Money and the morality of exchange. Jonathan Parry and Maurice Bloch, eds. Pp. 1-32. Cambridge: Cambridge University Press.

Boissevian, Jeremy. 1977. When the saints go marching out: reflections on the decline of patronage in Malta. In Patrons and clients in Mediterranean societies. Ernest Gellner and John Waterbury, eds. Pp. 81-97. London: Duckworth.

Braga, Juliana. 2013. Bolsa Família verreu o clientelismo do país, afirma Dilma. O Globo Online, October 30, política section. http://g1.globo.com/politica /noticia/2013/10/bolsa-familia-varreu-o-clientelismo-do-pais-diz-dilma-rousseff .html.

Brasil de Fato. 2017. Bolsa Família: Governo Temer promove o meior corte da história. Brasil de Fato, August 11, pobreza section. https://www.brasildefato .com.br/2017/08/11/bolsa-familia-governo-temer-promove-o-maior-corte-da -historia/.

Buarque de Hollanda, Sérgio. 2012 (1936). Roots of Brazil. G. H. Summ, trans. Notre Dame, IN: University of Notre Dame Press.

Campos, Álvaro. 2016. Para Gilmar Mendes, Bolsa Família é compra de voto institucionalizada. Estadão, October 21, política section. http://politica.estadao .com.br/noticias/geral,para-gilmar-mendes-bolsa-familia-e-compra-de-voto -institucionalizada, 10000083508.

Châtelet, Gilles. 2013. To live and think like pigs: the incitement of envy and boredom in market democracies. R. Mackay, trans. New York: Sequence.

DaMatta, Roberto. 1991. Carnivals, rogues and heroes: an interpretation of the Brazilian dilemma. J. Drury, trans. Notre Dame, IN: University of Notre Dame Press.

Elyachar, Julia. 2005. Markets of dispossession: NGOs, economic development, and the state in Cairo. Durham, NC: Duke University Press.

Fenwick, Tracy. 2015. Avoiding governors: federalism, democracy and poverty alleviation in Brazil and Argentina. Notre Dame, IN: University of Notre Dame Press.

Ferguson, James. 1994. The anti-politics machine: development, depoliticization, and bureaucratic power in Lesotho. Minneapolis: University of Minnesota Press.

Fox, Jonathan. 1997. The difficult transition from clientelism to citizenship: lessons from Mexico. In The new politics of inequality in Latin America: rethinking participation and representation. Douglas A. Chalmers, Carlos M. Vilas, Katherine Hite, Scott B. Martin, Kerianne Piester, and Monique Segarra, eds. Pp. 391-421. Oxford: Oxford University Press. 
Fukayama, Francis. 2014. Political order and political decay: from the Industrial Revolution to the globalization of democracy. New York: Farrar, Straus, and Giroux.

Gallas, Daniel. 2016. Dilma Rousseff's impeachment: how did it go wrong for her? BBC News Online, May 12, Latin America section. http://www.bbc.com /news/world-latin-america-36028247.

Gellner, Ernest. 1977. Patrons and clients. In Patrons and clients in Mediterranean societies. Ernest Gellner and John Waterbury, eds. Pp. 1-6. London: Duckworth.

Goldman, Marcio. 2013. How democracy works: an ethnographic theory of politics. Canon Pyon, UK: Kingston.

Graham, Richard. 1990. Patronage and politics in nineteenth-century Brazil. Stanford, CA: Stanford University Press.

Hagene, Turid. 2014. Political clientelism in Mexico: bridging the gap between citizens and the state. Latin American Politics and Society 57(1): 139-162.

Heredia, Beatriz. 1996. Política, família e comunidade. In Antropolopgia, voto e representação política. Moacir Palmeira and Maucio Goldman, eds. Pp. 5772. Rio de Janeiro, Brazil: Contra Capa.

Herzfeld, Michael. 1987. Anthropology through the looking glass. critical ethnography in the margins of Europe. Cambridge: Cambridge University Press.

Hetherington, Kregg. 2018. Peasants, experts, clients, and soybeans: the fixing of Paraguay's civil service. Current Anthropology 59(suppl. 18):S171-S181.

Hicken, Allen. 2011. Clientelism. Annual Review of Political Science 14:289310.

Holston, James. 2008. Insurgent citizenship: disjunctions of democracy and insurgency in Brazil. Princeton, NJ: Princeton University Press.

Kant, Immanuel. 2002 (1785). Groundwork for the metaphysics of morals. A. Wood, trans. and ed. New Haven, CT: Yale University Press.

Kawata, Junichi, ed. 2006. Comparing political corruption and clientelism. Hampshire, UK: Ashagate.

Landé, Carl. 1977. The dyadic basis of clientelism. In Friends, followers and factions: a reader in political clientelism. Steffen Schmidt, James Scott, Carl Landé, and Laura Guasti, eds. Pp. xiii-xxxvii. Berkeley: University of California Press.

Marques, Ana Claudia D. R. 1999. Algumas faces de outros eus. honra e patronagem na antropologia do mediterrâneo. Mana 5(1):131-147.

Marques, Ana Claudia, and Jorge Mattar Villela. 2016. The illusions and disillusions of electoral processes in Northeast Brazil. Paper presented at the 115th American Anthropological Association Annual Meeting, Minneapolis, $\mathrm{MN}$.

Mauss, Marcel. 1950 (1925). The gift: the form and reason for exchange in archaic societies. London: Routledge.

Muniz de Albuquerque, Durval, Jr. 2014 (1999). The invention of the Brazilian northeast. J. D. Metz, trans. Durham, NC: Duke University Press.

Munn, Nancy. 1992. The fame of the gawa: the symbolic study of value transformation in a Massim (Papua New Guinea) society. Durham, NC: Duke University Press.
Nugent, David. 2018. Corruption now and then: managing threats to the nation in twentieth-century Peru. Current Anthropology 59(suppl. 18):S28-S36.

Nunes Leal, Victor. 1977 (1949). Coronelismo: the municipality and representative government in Brazil. J. Henfrey, trans. Cambridge: Cambridge University Press.

Palmeira, Moacir. 1992. Voto: racionalidade ou significado. Revista Brasileira de Ciencias Sociais 7(20):26-30.

Peixoto, Socorro Letícia Fernandes. 2010. Os signficados do Programa Bolsa Família na vida das mulheres: um estudo na comunidade Morro da Vitória. MA Thesis, Universidade Estadual do Ceará.

Pitt-Rivers, Julian Alfred. 1954. The people of the Sierra. New York: Criterion. Porto, Walter Costa. 2002. O voto no brasil: da colônia à 6 a república. Rio de Janeiro, Brazil: Topbooks.

Rassam, Amal. 1977. Al-Taba'iyya: power, patronage and marginal groups in northern Iraq. In Patrons and clients in Mediterranean societies. Ernest Gellner and John Waterbury, eds. Pp. 157-167. London: Duckworth.

Roniger, Luiz. 1991. Hierarchy and trust in modern Mexico and Brazil. New York: Praeger.

Scott, James. 1977. Patronage or exploitation? In Patrons and clients in Mediterranean societies. Ernest Gellner and John Waterbury, eds. Pp. 21-41. London: Duckworth.

Sharma, Aradhana. New brooms and old: sweeping up corruption in India, one law at a time. Current Anthropology 59(suppl. 18):S72-S82.

Silva, Thiago, and Estevão Silva. 2015. Eleições no Brasil antes da democracia: o código eleitoral de 1932 e os pleitos de 1933 e 1934. Revista de Sociologia Política 23(56):75-106.

Singer, Matthew. 2009. Buying voters with dirty money: the relationship between clientelism and corruption. Paper presented to American Political Science Association 2009 Annual Meeting, Toronto.

Schwarz, Roberto. 1992. Misplaced ideas: essays on Brazilian culture. London: Verso.

Stokes, Susan, Thad Dunning, Marcelo Nazareno, and Valeria Brusco. 2013 Brokers, voters, and clientelism: the puzzle of distributive politics. Cambridge: Cambridge University Press.

Szwarcberg, Mariela. 2015. Mobilizing poor voters: machine politics, clientelism, and social networks in Argentina. Cambridge: Cambridge University Press.

Tidey, Sylvia. A tale of two mayors: configurations of care and corruption in eastern Indonesian direct district head elections. Current Anthropology 59 (suppl. 18):S117-S127.

Tribunal Superior Eleitoral Brasileiro. 2016. Código eleitoral anotado. 12th edition. Brasília, Brazil: Tribunal Superior.

Villela, Jorge Mattar. 2005. O dinheiro e suas diversas faces nas eleições municipais em Pernambuco. Mana 11(1):267-296.

Villela, Jorge Mattar, and Ana Claudia D. R. Marques. 2006. Municipal elections: favor, vote and credit in the Pernambucan sertão of Brazil. B. D. Willis, trans. Latin Americanist 49(2):25-63.

Wolf, Eric. 1966. Kinship, friendship, and patron-client relations in complex societies. In The social anthropology of complex societies. Michael Banton, ed. Pp. 1-22. Edinburgh, Scotland: Tavistock. 